УДК 504.3.054

\title{
ОЦНКА ЕКОЛОГІЧНОЇ НЕБЕЗПЕКИ АТМОСФЕРНОГО ПОВІТРЯ УРБОЕКОСИСТЕМИ ЗА СТАНОМ ДЕПОНУЮЧОГО СЕРЕДОВИЩА
}

\author{
Барабаш О. В., к.біол.н., доцент Національного транспортного університету, \\ M. Kü̈, e-mail: el_barabash@ukr.net, ORCID:0000-0001-5206-2922
}

\begin{abstract}
Діяльність промислових підприємств та викиди автомобільного транспорту є основними джерелами забруднення урбоекосистем і становлять суттєву загрозу здоров'ю населення міст в результаті емісії пилу в атмосферу. Висока кумулятивна здатність токсичних металів, зокрема плюмбуму призводить до його надходження в атмосферне повітря, трунти та підземні води, а в кінцевому підсумку - до накопичення в тканинах та органах рослинних організмах. Існує залежність між вмістом токсичних металів в атмосферному повітрі й випадінням їх в межах санітарнозахисної зони промислових та автотранспортних підприємств і поширенням по всій території урбоекосистеми. Сніговий покрив депонує забруднення, тому досить часто використовується для проведення оцінки стану атмосферного повітря. Пошаровий відбір проб снігового покриву дозволяє встановити динаміку забруднення та вплив виробничих потужностей підприємств на стан урбоекосистеми. Застосування методів біотестування за допомогою рослинних організмів, які використовуються в якості тест-об'єктів, засноване на їх чутливості до екзогенного хімічного впливу і відображується в реакиії-відповіді рослин на забруднювальні речовини. Визначення фізикохімічних показників снігового покриву та розрахунок фітотоксичного ефекту на основі методів фітотестування дозволяє виявити не лише присутність у сніговому покриві токсичних металів, але й отримати достовірну інформацію про їх розподіл в атмосферному повітрі міст. За результатами проведених досліджень отримано показники довжини пагонів Lepidium sativum. Tест-об'єкт був пророщений у пробах снігового покриву, відібраного на відстані 5-50 м поблизу підприємства АЗС «WOG». Отримані дані порівнювались із значеннями довжини пагонів тест-об'єкті, в пророщених у пробах снігу, з території паркової зони. Встановлено, що рівень забруднення атмосферного повітря токсичними металами на відстані 50 м від $A 3 C$ «WOG є найвищим. Фізико-хімічні показники снігового покриву та фітотоксичний ефект вказують на високу ймовірність потрапляння токсичних металів в атмосферне повітря за межі санітарно-захисної зони АЗC «WOG».

Ключові слова: фітоіндикація, тест-об'єкт, сніговий покрив, фітотоксичний ефект, крес-салат (Lеріdium sativum), урбоекосистема.
\end{abstract}

\section{DOI: 10.33815/2313-4763.2019.1.20.071-078}

Вступ. За результатами геохімічних та гігієнічних досліджень багато науковців відзначають залежність між вмістом токсичних металів в атмосферному повітрі й випадінням їх на території міст, що фіксується у вигляді аномалій у сніговому покриві як природному середовищі [1]. При утворенні й випадінні снігу в результаті процесів сухого та вологого вимивання концентрація забруднювальних речовин у ньому виявляється зазвичай у 2-3 рази вища, ніж в атмосферному повітрі, оскільки сніговий покрив депонує забруднення, дозволяючи проводити оцінку стану атмосферного повітря [2]. Пошаровий відбір проб снігового покриву надає перспективи в отриманні даних 3 динаміки забруднення атмосферного повітря міст за зимовий період, а відбір проб по всій площі снігового покриву - можливість одержати дані про забруднення в період від утворення стійкого снігового покриву до моменту відбору проби. Вміст токсичних речовин у сніговому покриві визначають досить простими методами й з високим ступенем надійності, тим більше, що в умовах великих міст зі складною промислово-селітебною забудовою спостерігається обмежена кількість стаціонарних постів, що не дозволяє отримати достовірну інформацію щодо просторового розподілу забруднювальних речовин по всій території [1]. Використання біоіндикаційних методів моніторингу, зокрема фітотестування за допомогою чутливого тест-об'єкта крес-салату (Lepidium sativum) дозволять досить дешево і просто у виконанні проводити контроль якості середовища на присутність токсичних речовин у сніговому покриві в безперервному режимі та без попередньої ідентифікації конкретних хімічних сполук або фізичних впливів [3].

Аналіз досліджень. 3 геологічної позиції до досліджень снігу першим підійшов П. Н. Чирвінський, який розглядав сніговий покрив як невід'ємну частину системи: атмосфера - грунтовий покрив - водоносний горизонт [4]. Питання моніторингу 
забруднення снігового покриву розкриваються у наукових роботах В. Н. Василенка, I. М. Назарова [5]; В. М. Артемова та ін. [6]. На думку С. І. Сгорової [7] виключно методами біотестування можна оцінити кумулятивний ефект різноманіття впливів. Біотестування як вступ до більш детального й усебічного аналізу хімічного складу атмосферного повітря, грунтів чи води, розглядає у своїй праці I. Н Тарасенко [8]. Контроль за станом та оцінка фітотоксичного потенціалу компонентів біосфери висвітлена у багатьох наукових працях вітчизняних і зарубіжних авторів [9-14].

Матеріали та методика дослідження. Проби снігового покриву отримували враховуючи межі санітарно-захисної зони АЗС [15]. Щільність відбору складала 1-5 проб на км², що пов'язано з можливістю виявлення епіцентру забруднення. Проби відбирали на всю потужність снігоприймача та фіксували площу шурфу й снігодоби. Розміри шурфу заміряли по довжині і ширині для розрахунку площі, на яку проєктується випадіння 3 атмосфери. Вага проб досягала 6 кг, що дозволило отримати масу випадінь, достатню для проведення аналізу. Дату відбору чітко фіксували для визначення часу накопичення в сніговому покриві атмосферних опадів. Відібрані проби розтоплювали й центрифугували для видалення твердої фракції опадів. Органолептичний показник (запах) проб снігу оцінювали за 5-бальною шкалою. Хімічні методи використовували для визначення водневого показника (pH) $[15,16]$.

Фітотестування снігового покриву за допомогою тест-об'єкта проводили протягом 10 днів. Партію насіння крес-салату, призначену для дослідів, перевіряли на проростання. За норму приймали 90-95 \% пророслих від числа посіяних насінин [3].

Після проведення вимірювань для кожного з досліджуваних варіантів обчислювали середню довжину надземної і кореневої частин $x \pm m$, де $m-$ помилка середнього арифметичного, яку визначали:

$$
m=\sqrt{\frac{\sigma^{2}}{N}}
$$

де $N$ - кількість результатів; $\sigma^{2}$ - дисперсія, яку визначають за виразом:

$$
\sigma^{2}=\frac{\sum_{i=1}^{N}(x-\bar{x})^{2}}{N} .
$$

Достовірність різниці середніх арифметичних $t$ розраховували за критерієм Стьюдента-Фішера:

$$
t=\frac{\bar{x}_{1}-\bar{x}_{2}}{\sqrt{m_{1}^{2}+m_{2}^{2}}},
$$

де $x_{1}$ - середнє арифметичне значення показника в контрольному досліді; $x_{2}-$ середнє арифметичне значення показника у досліджуваному варіанті; $m_{1}$ - помилка середнього арифметичного в контрольному досліді; $m_{2}$ - те ж у досліджуваному варіанті.

Фітотоксичний ефект визначали у відсотках за одним біопараметром - довжиною пагона й розраховували за формулою:

$$
\Phi E=\frac{M_{0}-M_{x}}{M_{o}} * 100 \%,
$$

де $M о$ - значення біопараметра (маса рослин, висота паростків, довжина корінців та ін.) у посуді з контрольним субстратом; $M x$ - значення аналогічного біопараметра у посуді 3 досліджуваним субстратом.

Основні результати дослідження. Шевченківський район - один із центральних районів м. Києва і займає площу 2,7 тисяч гектарів, населенням якого складає 233,5 тис. чоловік. Шевченківський район поєднує в собі високопродуктивну промисловість (табл. 1) і будівництво, поліграфічне виробництво й розгалужену торгівлю, охорону здоров'я і сферу побутового обслуговування, широку мережу навчальних закладів та закладів культури. 
Науковий вісник Херсонської державної морської академії № 1 (20), 2019

Таблиця 1 - Підприємства Шевченківського району м. Києва

\begin{tabular}{|l|c|}
\hline \multicolumn{2}{|c|}{ Кількість підприємств, які звітували за формою №1Пу 2018 році-59 підприємств } \\
\hline Галузева структура промисловості по видах економічної діяльності & Питома вага, \% \\
\hline Промисловість & 100,0 \\
\hline Переробна промисловість: & 15,8 \\
\hline харчова промисловість та перероблення сільськогосподарських продуктів & 15,8 \\
\hline Легка промисловість: & 0,7 \\
\hline текстильна промисловість та пошиття одягу & 0,7 \\
\hline виробництво шкіри та шкіряного взуття & 0,3 \\
\hline Виробництво деревини та виготовлення виробів з неї \\
\hline Целюлозно-паперова, поліграфічна промисловість та видавнича справа \\
\hline Хімічна і нафтохімічна промисловість: & 24,7 \\
\hline хімічне виробництво & 22,5 \\
\hline виробництво гумових та пластмасових виробів & 22,3 \\
\hline $\begin{array}{l}\text { Виробництво інших неметалевих мінеральних виробів (будматеріалів та } \\
\text { скловиробів) }\end{array}$ \\
\hline Металургія та оброблення металу \\
\hline Машинобудування, ремонт та монтаж машин і устаткування \\
\hline виробництво машин і устаткування & 0,2 \\
\hline виробництво електричного та електронного устаткування & 2,7 \\
\hline виробництво транспортного устаткування & 33,3 \\
\hline
\end{tabular}

Отже, промисловість району складають різногалузеві підприємства м. Києва, зокрема ДАХК «Артем», ПрАТ КЗБН «Росинка», ВАТ «НВК Київський завод автоматики ім. Г. І. Петровського», ВАТ КЕЗ «Транссигнал», ДП «Дослідний завод зварювальних матеріалів ім. Є. О. Патона», ДП Поліграфкомбінат «Україна», ДП Видавництво «Преса України», ДП ВАТ «Київхліб» «Булочно-кондитерський комбінат», ДП ВАТ «Київхліб» «Дослідний хлібозавод», АТ «Київмедпрепарат» [17].

Загрозлива ситуація в районі створюється через стрімке збільшення автотранспортних потоків. Найбільше потерпають мешканці, що проживають у безпосередній близькості до розв'язок та перехресть 3 недостатніми пропускними можливостями. Відповідно до результатів спостережень Центральної геофізичної обсерваторії в Шевченківському районі великою екологічною небезпекою характеризуються проспект Перемоги, площа Перемоги та Бессарабська площа. Бессарабська площа є найбільш забрудненим місцем у Києві, де інтегральний показник забруднення атмосфери постійно характеризується як високий. Рівні завислих речовин, фенолу, діоксиду нітрогену та формальдегіду перевищують гранично допустимі концентрації мінімум удвічі.

Загальний рівень забруднення повітря за індексом забруднення атмосфери (I3A) у Шевченківському районі м. Києва оцінюється як високий [17]. Загалом по району відзначається перевищення середньодобових гранично допустимих концентрацій (ГДКс.д.) діоксиду нітрогену, формальдегіду, оксиду нітрогену та фенолу. Це речовини 2 і 3 класів небезпеки, які що протягом усього року найбільшою мірою забруднюють повітря досліджуваного району. Вміст діоксиду нітрогену за середньорічними та максимальними концентраціями перевищує рівень відповідних ГДК на всіх постах Шевченківського району. Вміст важких металів у 2018 р. був нижче рівня допустимих норм, а середньорічні концентрації кадмію, заліза, мангану, купруму, нікелю, плюмбуму, хрому та цинку на всіх постах були на рівні 0,0-0,1 ГДКс.д [17].

Перевищення ГДК за діоксином нітрогену, оксидом вуглецю, формальдегідом пилом установлені на всіх автомагістралях району. Найбільші перевищення виявлені на вул. Січових Стрільців, вул. О.Теліги, просп. Перемоги, вул. Б. Хмельницького, бульв. Т. Шевченка. В зоні впливу промислових підприємств Шевченківського району за вмістом діоксиду нітрогену перевищення спостерігаються: ПАТ «Київобленерго» вул. Стеценка, 1; ДАХК «Артем» вул. Мельникова, 2/10; ПП Фірма «КІМС» 
вул. Дмитрівська, 18-24; АЗС «WOG» просп. Перемоги, 11-Б; АЗС «АМIC» вул. Дегтярівська, 53; АЗС «АМІС» вул. Табірна, 46/48; ПАТ «Пластмаш»; котельні гуртожитку МАУП.

Зважаючи на те, що склад снігового покриву змінюється залежності від його віддаленості від джерела забруднення, для отримання достовірних даних про рівень забруднення атмосферного повітря проби снігу відбирали на майданчиках розміром не менше 1 м $^{2}$ на відстані 5, 10, 20 та 50 м від A3C «WOG». Контрольним зразком стала проба в районі Ботанічного саду імені академіка Олександра Фоміна. Термін контакту снігового покриву з навколишнім середовищем від часу випадіння снігу до збору проби складав у січні 10 днів, а в лютому 14 днів (табл. 2).

Таблиця 2 - Дані про відбір проб

\begin{tabular}{|c|c|c|}
\hline № nроби & Yac & Місце \\
\hline \multicolumn{3}{|r|}{ Січень } \\
\hline 1 & 16.01 .2019 & $\mathrm{~A} 3 \mathrm{C} \ll \mathrm{WOG} »(5 \mathrm{~m})$ \\
\hline 2 & 16.01 .2019 & $\mathrm{~A} 3 \mathrm{C} \ll \mathrm{WOG} »(10 \mathrm{~m})$ \\
\hline 3 & 16.01 .2019 & $\mathrm{~A} 3 \mathrm{C} \ll \mathrm{WOG} »(20 \mathrm{~m})$ \\
\hline 4 & 16.01.2019 & A3C «WOG» $(50 \mathrm{~m})$ \\
\hline 5 & 16.01 .2019 & Ботанічний сад імені академіка Олександра Фоміна \\
\hline \multicolumn{3}{|r|}{ Лютий } \\
\hline 1 & 16.02 .2019 & $\mathrm{~A} 3 \mathrm{C} \ll \mathrm{WOG} »(5 \mathrm{~m})$ \\
\hline 2 & 16.02.2019 & $\mathrm{A} 3 \mathrm{C} \ll \mathrm{WOG} »(10 \mathrm{~m})$ \\
\hline 3 & 16.02 .2019 & $\mathrm{~A} 3 \mathrm{C} \ll \mathrm{WOG} »(20 \mathrm{~m})$ \\
\hline 4 & 16.02 .2019 & $\mathrm{~A} 3 \mathrm{C} \ll \mathrm{WOG} »(50 \mathrm{~m})$ \\
\hline 5 & 16.02 .2019 & Ботанічний сад імені академіка Олександра Фоміна \\
\hline
\end{tabular}

За результатами дослідження встановлено, що найбільший вміст розчинних домішок спостерігався в пробі, відібраній на відстані 5 м від АЗС у січні, тоді як у лютому найбільший вміст розчинених домішок відзначався у пробі снігу з відстані 50 м від АЗС. Найменший вміст розчинних домішок виявлено у контролі. Такі показники пов'язані не лише 3 діяльністю АЗС, але й 3 наявністю інтенсивного автомобільного руху з боку проспекту Перемоги.

Встановлюючи величину $\mathrm{pH}$ снігу відзначаємо, що вона може бути обумовлена наявністю в атмосфері не тільки твердих частинок, але й газоподібних забруднювальних речовин: $\mathrm{SO}_{2}, \mathrm{CO}, \mathrm{CO}_{2}, \mathrm{~N}_{2} \mathrm{O}, \mathrm{NO}, \mathrm{NO}_{2}$, які після танення снігу перейдуть у грунтове середовище. Чистий сніг, як і чиста дощова вода, має $\mathrm{pH}=5,6$, що пов'язано з наявністю в повітрі $\mathrm{CO}_{2}$, який підкислює атмосферні опади [15]. Якщо в повітрі багато оксидів нітрогену, сірчистого газу, діоксиду сульфуру та інших кислотних основ, то сніг буде мати величину $\mathrm{pH}<5,6$. При $\mathrm{pH}$ снігу вище 5,6 є вірогідність його забруднення оксидами металів. Середній показник $\mathrm{pH}$ у досліджуваних пробах снігу коливався в межах від 5,25 (5-10 м від АЗС) до 5,75 (20 м від АЗС), що доводить неоднорідність розподілу забруднювальних речовин та надзвичайний вплив викидів автомобільного транспорту. Таким чином, за показником $\mathrm{pH}$ найбільше оксидів нітрогену, сірчистого газу, діоксиду сульфуру містять проби снігу відібрані на відстані 5 та 10 м від АЗС у січні. Лужне середовище, а відтак i забруднення оксидами металів виявлено у пробах на відстані 20 м від АЗС у січні та лютому.

За оцінкою органолептичних показників проб снігових опадів, згідно з ДСТУ ISO 7027:2003 «Якість води. Визначення каламутності» виявлено, що високим рівнем прозорості по відношенню до інших зразків відрізняється снігова вода контрольної проби 
[18]. Сильна мутність спостерігається у пробах, відібраних біля АЗС на відстані 5 м та 10 м, що можливо пов'язано 3 наявністю неорганічних i органічних тонкодисперсних суспензій. піску, глини, неорганічних сполук (гідроксиду алюмінію, карбонатів різних металів), а також органічних домішок, окислювання сполук заліза й марганцю киснем повітря. Найбільш інтенсивний землянистий запах зафіксовано у пробах узятих у січні в районі найбільшої близькості до АЗС (5 та 10 м). У решти проб запах снігової води теж мав природнє походження, що пов'язано $з$ життєдіяльністю живих і відмерлих організмів, наявністю рослинних залишків, специфічних речовин, які виділяються деякими мікроорганізмами.

Рослини як первинні ланки трофічних ланцюгів відіграють головну роль у поглинанні різного роду речовин та $є$ найбільш зручними індикаторами забруднення навколишнього середовища. Тому за допомогою рослин можна достатньо точно оцінити екологічну ситуацію на досліджуваній території. Сенс ростового тесту полягає в обліку змін показників проростання індикаторної культури, вирощеної на досліджуваних зразках грунту, води, водних витяжок грунтів тощо. Цей метод дозволяє оцінити не тільки пригноблювальну дію різних забруднювачів на рослини, але і стимулювальний ефект.

За методикою Т.Я. Ашихміної визначали рівень забруднення снігового покриву біля підприємства $\mathrm{A} 3 \mathrm{C}$ «WOG» за допомогою насіння крес-салату. Експеримент проводився протягом 10 днів після танення снігу й досягнення сніговою водою кімнатної температури. В чашки Петрі розміщували по 50 насінин крес-салату на фільтрувальний папір, змочений у досліджуваних пробах снігової води. Довжину пагонів починали вимірювати через 24 години, а потім кожного дня протягом усього часу, відведеного на експеримент. Довжину пагонів вимірювали за допомогою штангель-циркуля 3 точністю до 0,1 см.

Аналізуючи реакцію тест-об'єкта на вміст токсичних металів в сніговому покриві на різній відстані від АЗС установлено, що ступінь пригніченості росту рослинних організмів складає близько 53 \% у січні та більше 60 \% у лютому порівняно з контролем. Зауважимо, що найбільший відсоток пригнічення відзначено у рослин, пророщених у пробах, відібраних на відстані 10 та 50 м від джерела забруднення у січні та лютому.

На основі отриманих даних був розрахований фітотоксичний ефект від дії викидів АЗС на крес-салат, який є чутливим індикатором щодо надходження у навколишнє середовище сполук токсичних металів (табл. 3).

Таблиця 3 - Фітотоксичний ефект

\begin{tabular}{|c|c|c|c|c|c|c|c|c|}
\hline \multirow{3}{*}{ Параметр } & \multicolumn{8}{|c|}{$A 3 C$ «WOG» (Шевченківський район м. Києва) } \\
\hline & & \multicolumn{3}{|c|}{ Крес-салат (\%) (січень) } & \multicolumn{4}{|c|}{ Крес-салат (\%) (лютий) } \\
\hline & $5 \mathrm{M}$ & $10 \mathrm{M}$ & $20 \mathrm{M}$ & $50 \mathrm{M}$ & $5 \mathrm{M}$ & $10 \mathrm{M}$ & $20 \mathrm{M}$ & $50 \mathrm{M}$ \\
\hline$\Phi \mathrm{E}$ & 46,48 & 56,34 & 36,62 & 49,30 & 21,03 & 66,67 & 28,21 & 30,77 \\
\hline
\end{tabular}

Таким чином, процеси пригноблення ростових процесів порівняно з контролем були найвагомішими у пробах, узятих на відстані 10 та 50 м від джерела забруднення.

Висновки. Установлено, що рівень забруднення токсичними металами атмосферного повітря $є$ досить високим як поблизу, так і на відстані від АЗС, розташованої в Шевченківському районі м. Києва. Отримані показники довжини пагонів, фізико-хімічні показники снігового покриву та фітотоксичний ефект від впливу діяльності A3C «WOG» на рослинні організми порівняно 3 контрольним зразком указують на високу ймовірність потрапляння токсичних металів в атмосферне повітря не лише за межі санітарно-захисної зони АЗС, але й на територію селітебної зони району. 


\section{СПИСОК ВИКОРИСТАНОЇ ЛІТЕРАТУРИ}

1.Baran A., Jasiewicz C., Antonkiewicz J. Testing toxicity of oily grounds using phytotoxkit tests . The First Joint PSE-SETAC Conference on Ecotoxicology. Book of Abstracts. Poland, 2009, poster.

2. Барабаш О. В., Солодка Ю. В. Оцінка інтенсивності забруднення снігового покриву придорожньої зони м. Києва як показник забруднення атмосферного повітря. Вісник Національного транспортного університету. 2011. Вип. 22. С.46-52.

3. Ашихмина Т.Я. Экологический мониторинг. М.: Академический проект, 2005. 416 c.

4. Чирвинский П. Н. Снег и снегозадержание: с приложением атласа. Ростов-на-Дону : Севверный Кавказ, 1931. 240 с.

5. Мониторинг загрязнения снежного покрова / Василенко В. Н., Назаров И. М., Фридман Ш. Д. и др. Л. : Гидрометеоиздат, 1985. 182 с.

6. Артемов В. М., Парцеф Д. П., Сает Ю. Е. Анализ состояния загрязнения снегового покрова для проектирования сети станций АНКОС-А. Методические $u$ системотехнические вопросы контроля загрязнения окружающей среды: труды ИМПГ. 1982. Вып. 48. С. $144-149$.

7. Inês A.PinhoDaniela V.LopesRui C.MartinsMargarida J.Quin Phytotoxicity assessment of olive mill solid wastes and the influence of phenolic compounds. Chemosphere 2017.Vol. 185. P $258-267$

8. Tesfamichael H. Kebrom, Selamawit Woldesenbet, Haimanote K. Bayabil, Monique Garcia, Ming Gao, Peter Ampim, Ripendra Awal, Ali Fares. Evaluation of phytotoxicity of three organic amendments to collard greens using the seed germination bioassay. Environmental Science and Pollution Research. 2019. Vol. 26. Issue 6. P. 5454-5462.

9. Aranda E., García-Romera I., Ocampo J.A., Carbone V., Mari A., Malorni A. C. Chemical characterization and effects on Lepidium sativum of the native and bioremediated components of dry olive mill residue. Chemosphere. 2012. Vol. 69 (2). P. 229-239.

10. Manual for the evaluation of laboratories performing aquatic toxicity tests. U.S. Environmental Protection Agency, Office of Research and Development. EPA/600/4-90/031. 1991, 108 p.

11. Blok, C., Persoone, G. and Wever, G. A practical and low cost microbiotest to assess the phytotoxic potential of growing media and soil. Acta Hortic. 2008. № 779. P. 367-374

12. Биотестирование и биоиндикация окружающей среды : Учеб. пособие по курсу «Биотестирование» / Е. И. Егорова, В. И. Белолипецкая; м-во образования Рос. Федерации. Обнин. ин-т атом. энергетики. Фак. естеств. наук. Обнинск: Обнин. ин-т атом. энергетики, $2000.78 \mathrm{c}$.

13. Тарасенко И. Н. К вопросу о биотестировании. Экология и охрана окружающей средbl. 1999. №5. С. 56-59.

14. Буштуева К.А., Парцеф Д.П., Беккер А.А., Ревич Б.А. Выбор зон наблюдений в крупных промышленных городах для выявления влияния атмосферных загрязнений на здоровье населения. Гигиеническая санитария. 1964. № 1. С. 4-6.

15. Методические рекомендации по оценке степени загрязнения атмосферного воздуха населенных пунктов металлами по их содержанию в снежном покрове и почве (утв. главным государственным санитарным врачом СССР от 15.05.1990 N 5174-90). 17c.

16. Безкопыльный И.Н. Некоторые методические подходы к изучению воздействия факторов окружающей среды на здоровье населения в зоне территориальнопроизводственного комплекса. Гигиеническая санитария. 1984. № 11. С. $24-27$.

17. Шевченківська районна в місті Києві державна адміністрація. URL: https://shev.kyivcity.gov.ua/content/menyu-2.html (дата звернення: 15.09.2019).

18. Центральна геофізична обсерваторія імені Бориса Срезневського. URL: http://cgo-sreznevskyi.kiev.ua/ (дата звернення: 02.09.2019). 


\section{REFERENCES}

1.Baran A., Jasiewicz C., Antonkiewicz J. (2009). Testing toxicity of oily grounds using phytotoxkit tests. The First Joint PSE-SETAC Conference on Ecotoxicology. Book of Abstracts. Poland, poster.

2. Barabash O. V., Solodka Yu. V. (2011). Otsinka intensyvnosti zabrudnennya snihovoho pokryvu prydorozhn'oyi zony $\mathrm{m}$. Kyyeva yak pokaznyk zabrudnennya atmosfernoho povitrya. Visnyk Natsional'noho transportnoho universytetu. 22, 46-52.

3. Ashykhmyna T.YA. (2005). Ékolohycheskyy monytorynh. M.: Akademycheskyy Proekt.

4. Chyrvynskyy P.N. (1931). Sneh y snehozaderzhanye: s prylozhenyem atlasa. Rostovna-Donu: Sevvernyy Kavkaz.

5. Vasylenko V.N., Nazarov Y.M., Frydman Sh. D. (1985). Monytorynh zahryaznenyya snezhnoho pokrova. L.: Hydrometeoyzdat.

6. Artemov V.M., Partsef D.P., Saet Yu.E. (1982). Analyz sostoyanyya zahryaznenyya snehovoho pokrova dlya proektyrovanyya sety stantsyy ANKOS-A. V kn.: Metodycheskye y systemotekhnycheskye voprosy kontrolya zahryaznenyya okruzhayushchey sredy. Trudy YMPH.

7. Inês A.PinhoDaniela V.LopesRui C.MartinsMargarida J.Quin (2017). Phytotoxicity assessment of olive mill solid wastes and the influence of phenolic compounds. Chemosphere https://doi.org/10.1016/j.chemosphere.2017.07.002

8. Tesfamichael H. Kebrom, Selamawit Woldesenbet, Haimanote K. Bayabil, Monique Garcia, Ming Gao, Peter Ampim, Ripendra Awal, Ali Fares. (2019). Evaluation of phytotoxicity of three organic amendments to collard greens using the seed germination bioassay. Environmental Science and Pollution Research. 26, 6, 5454-5462.

9. Aranda E., García-Romera I., Ocampo J.A., Carbone V., Mari A., Malorni A. C (2012). Chemical characterization and effects on Lepidium sativum of the native and bioremediated components of dry olive mill residue. Chemosphere. 69 (2), .229-239.

10. Manual for the evaluation of laboratories performing aquatic toxicity tests (1991). U.S. Environmental Protection Agency, Office of Research and Development. EPA/600/4-90/031. Cincinnati.

11. Blok, C., Persoone, G. and Wever, G. (2008). A practical and low cost microbiotest to assess the phytotoxic potential of growing media and soil. Acta Hortic. 779, 367-374.

12. Yegorova Ye.I., Belolipetskaya V.I. (2000). Biotestirovaniye $i$ bioindikatsiya okruzhayushchey sredy : Ucheb. posobiye po kursu «Biotestirovaniye». Obninsk : Obnin. in-t atom. Energetiki.

13. Tarasenko I.N. (1999). K voprosu o biotestirovanii. Ekologiya i okhrana okruzhayushchey sredy, 5, 56-59.

14. Bushtuyeva K.A., Partsef D.P., Bekker A.A., Revich B.A. (1964). Vybor zon nablyudeniy $v$ krupnykh promyshlennykh gorodakh dlya vyyavleniya vliyaniya atmosfernykh zagryazneniy na zdorov'ye naseleniya. Gig. Sanitariya, 1, 4-6.

15. Metodicheskiye rekomendatsii po otsenke stepeni zagryazneniya atmosfernogo vozdukha naselennykh punktov metallami po ikh soderzhaniyu v snezhnom pokrove i pochve (utv. glavnym gosudarstvennym sanitarnym vrachom SSSR ot 15.05.1990 N 5174-90.

16. Bezkopyl'nyy I.N. (1984). Nekotoryye metodicheskiye podkhody $k$ izucheniyu vozdeystviya faktorov okruzhayushchey sredy na zdorov'ye naseleniya $v$ zone territorial'noproizvodstvennogo kompleksa, 11, 24-27.

17. Shevchenkivs'ka rayonna v misti Kyyevi derzhavna administratsiya (2019). Retrieved from https://shev.kyivcity.gov.ua/content/menyu-2.html.

18. Tsentral'na heofizychna observatoriya imeni Borysa Sreznevs'koho (2019). Retrieved from http://cgo-sreznevskyi.kiev.ua/. 
Барабаш Е. В. ОЦЕНКА ЭКОЛОГИЧЕСКОЙ ОПАСНОСТИ АТМОСФЕРНОГО ВОЗДУХА УРБОЭКОСИСТЕМЫ ПО СОСТОЯНИЮ ДЕПОНИРУЮЩЕЙ СРЕДЫ

Деятельность промышленных предприятий и выбросы автомобильного транспорта являются основными источниками загрязнения урбоэкосистем и составляют существенную угрозу здоровью населения городов в результате эмиссии пыли в атмосферу. Высокая кумулятивная способность токсичных металлов, в частности свиниа, приводит к его поступлению в атмосферный воздух, почвы и подземные воды, а в итоге - к накоплению в тканях и органах растительных организмах. Существует зависимость между содержанием токсичных металлов в атмосферном воздухе и выпадением их в пределах санитарно-защитной зоны промышленных и автотранспортных предприятий, а также их распространением по всей территории урбоэкосистемы. Снежный покров депонирует загрязнения, поэтому довольно часто используется для проведения оченки состояния атмосферного воздуха. Послойный отбор проб снежного покрова позволяет установить динамику загрязнения и влияние производственных мощностей предприятий на состояние урбоэкосистемы. Применение методов биотестирования с помощью растительных организмов, используемых в качестве тест-объектов, основано на их чувствительности к экзогенному химическому воздействию и отображается в виде реакиий-ответов растений на загрязняющие вещества. Определение физико-химических показателей снежного покрова и расчет фитотоксического эффекта на основе методов фитотестирования позволяет выявить не только наличие в снежном покрове токсичных металлов, но и получить достоверную информачию об их распределении в атмосферном воздухе городов. По результатам проведенных исследований получены показатели длины побегов Lepidium sativum. Tест-объект был пророщен в снежном покрове отобранном на расстоянии от 5 до 50 м у предприятия $A 3 C$ «WOG». Полученные данные сравнивались со значениями длины побегов тест-объектов, пророщенных в пробах снега, с территории парковой зоны. Установлено, что уровень загрязнения атмосферного воздуха токсичными металлами на расстоянии 50 м от $A 3 C$ «WOG является самым высоким. Физико-химические показатели снежного покрова и фитотоксический эффект указывают на высокую вероятность попадания токсичных металлов за предель санитарно-защитной зоны $A 3 C$ «WOG».

Ключевые слова: фитоиндикация, тест-объект, снежный покров, фитотоксический эффект, кресс-салат (Lepidium sativum), урбоэкосистема

\section{Barabash O. V. ECOLOGICAL HAZARD ASSESSMENT OF THE ATMOSPHERIC AIR AT THE URBAN ECOSYSTEM BY THE STATE OF THE DEPOSIT ENVIRONMENT}

Industrial activity and emissions of road transport are considered to be the major sources of pollution in urban ecosystems and pose a significant threat to the health of urban population due to dust emissions into the atmosphere. The high cumulative capacity of toxic metals, in particular the plumbum, leads to its entry into the atmospheric air, soil and groundwater, and ultimately to accumulation in the tissues and organs of plant organisms. There is a correlation between the content of toxic metals in the atmospheric air and their fallout within the sanitary protection zone of industrial and motor transport enterprises and distribution throughout the urban ecosystem. Snow cover stores pollution, thus, it is often used to assess the state of the air. The layer-by-layer sampling of the snow cover allows to determine the pollution dynamics and the influence of the production capacities of enterprises on the state of the urban ecosystem. The bioassay methods using plant organisms as test objects are based on their sensitivity to exogenous chemical effects and are reflected in the response of plants to pollutants. Determination of physico-chemical parameters of the snow cover and calculation of phytotoxic effect based on the phytotesting methods allows to detect not only the presence of toxic metals in the snow cover, but also to obtain reliable information about their distribution in the atmospheric air of cities. According to the researches results, the indexes for the lengths of Lepidium sativum shoots have been obtained. The test object has been germinated in a snow cover sampled at a distance of 5 to $50 \mathrm{~m}$ near the VOG filling station enterprise. The data obtained has been compared with the values of the shoots length of test objects germinated in snow samples from the territory of the park area. It has been established that the level of atmospheric air pollution with toxic metals wass the highest at a distance of $50 \mathrm{~m}$ from VOG filling station. The physico-chemical parameters of the snow cover and the phytotoxic effect indicate a high probability of toxic metals entry into the atmospheric air beyond the limits of the sanitary protection zone of VOG filling station and into the residential areas.

Keywords: phytoindication, test object, snow cover, phytotoxic effect, garden cress (Lepidium sativum), urban ecosystem.

(C) Барабаш O. B.

Статтю прийнято

до редакції 03.03.19

До рубрики включено статті за тематичною спрямованістю

«Автомаизація та комп'ютерно-інтегровані технологї̈» 